\title{
Assessing rainfall erosivity indices through synthetic precipitation series and artificial neural networks
}

\author{
ROBERTO A. CECÍLIO ${ }^{1}$, MICHEL C. MOREIRA ${ }^{2}$, JOSÉ EDUARDO M. PEZZOPANE ${ }^{1}$, \\ FERNANDO F. PRUSKI ${ }^{3}$ and DANILO C. FUKUNAGA ${ }^{1}$ \\ ${ }^{1}$ Universidade Federal do Espírito Santo, Departamento de Engenharia Florestal, \\ Alto Universitáro, s/n, Caixa Postal 16, 29500-000 Alegre, ES, Brasil \\ ${ }^{2}$ Universidade Federal da Bahia, Instituto de Ciências Ambientais e Desenvolvimento Sustentável, \\ Rua Prof. José Seabra, s/n, 47805-100 Barreiras, BA, Brasil \\ ${ }^{3}$ Universidade Federal de Viçosa, Departamento de Engenharia Agrícola, Av. P.H. Rolfs, s/n, 36570-000 Viçosa, MG, Brasil
}

Manuscript received on March 12, 2012; accepted for publication on March 15, 2013

\begin{abstract}
The rainfall parameter that expresses the capacity to promote soil erosion is called rainfall erosivity (R), and is commonly represented by the indexes $\mathrm{EI}_{30}$ and $\mathrm{KE}>25$. The calculations of these indexes requires pluviographical records, that are difficult to obtain in Brazil. This paper describes the use of synthetic rainfall series to compute $\mathrm{EI}_{30}$ and $\mathrm{KE}>25$ in Espírito Santo State (Brazil). Artificial neural networks (ANNs) were also developed to spatially interpolate $\mathrm{R}$ values in Espírito Santo. $\mathrm{EI}_{30}$ and $\mathrm{KE}>25$ indexes values were close to those calculated on a homogeneous area according to the similarity of rainfall distribution; indicating the applicability of the use of synthetic rainfall series to estimate the R factor. ANNs had a better performance than Inverse Distance Weighted and Kriging to spatially interpolate rainfall erosivity values in the State of Espírito Santo.
\end{abstract}

Key words: interpolation, rainfall generator, soil conservation, universal soil loss equation.

\section{INTRODUCTION}

Soil erosion is a widespread land degradation problem in many parts of the world. On-site and off-site costs of soil erosion reach about 44 billion dollars in the United States (Pimentel et al. 1995), 4.2 billion dollars in Brazil (Hernani et al. 2002) and 45.5 billion dollars in the European Union (Telles et al. 2011). Assessing the risk of erosion, predicting erosion rates and designing and evaluating different soil protection strategies is an essential tool for selecting soil and watershed best management practices. Mathematical models are used to

Correspondence to: Roberto Avelino Cecílio

E-mail: roberto.cecilio@ufes.br quantify and predict soil losses. The universal soil loss equation (USLE) (Wischmeier and Smith 1978) and the revised universal soil loss equation (RUSLE) (Renard et al. 1991) have been the most widely used models in predicting soil erosion losses (Baskan et al. 2010).

Rainfall is the main climatic characteristic that influences soil erosion, given the extraordinary importance of soil detachment processes due to drop impact and runoff shear. Among USLE/ RUSLE factors, the erosive capacity of rainfall is expressed as rainfall erosivity (R), commonly represented by the indices $\mathrm{EI}_{30}$ (Wischmeier and Smith 1958) or KE>25 (Hudson 1973). 
The main method to calculate rainfall erosivity values requires pluviographic records. This kind of information is difficult to obtain in Brazil due to the reduced number and inadequate spatial distribution of meteorological stations that are equipped to provide pluviographic data. This makes it very difficult to know an $\mathrm{R}$ factor for all of Brazil. On the other hand, some empirical equations can also estimate values of rainfall erosivity by using geographical coordinates or pluviometric records, such as annual and monthly rainfall averages (Silva 2004, Hoyos 2005, Aquino et al. 2008, Capolongo et al. 2008, Zhang et al. 2008a).

Yu (2002) and Zhang et al. (2008b, 2010) assessed the ability of stochastic weather generators to generate daily rainfall synthetic series used to calculate the $\mathrm{R}$ factor. These generators have the potential to be used in Brazil to extend the rainfall erosivity index database.

Many authors (Qi et al. 2000, Silva 2004, Hoyos et al. 2005, Moreira et al. 2006, Yin et al. 2007, Men et al. 2008, Shamsad et al. 2008, Angulo-Martínez et al. 2009, Silva et al. 2010a, b, Alves Sobrinho et al. 2011) used spatial interpolation techniques like "inverse distance weighted", "kriging” and "artificial neural networks" (ANNs) to create maps representing spatial distribution of $\mathrm{R}$ values. Since no single interpolation method among those available for spatial interpolation of $\mathrm{R}$ factor is optimal for all regions and all indices, it is very important to compare the results obtained through different methods, applied to each set of data (Goovaerts 1999, Beguería and VicenteSerrano 2006, Angulo-Martínez et al. 2009).

The ability of ANNs to use different input parameters makes them capable of solving complex problems from many areas (Sárközy 1999, Souza et al. 2006). The ANNs are cited as an alternative resource for estimating climatic variables that may replace the traditional interpolation methods (Białobrzewski 2008, Sivapragasam et al. 2010), including rainfall erosivity indexes as assessed by Moreira et al. (2006) for São Paulo State, Brazil.
In this paper we aimed at: a) calculating rainfall erosivity indexes $\mathrm{EI}_{30}$ and $\mathrm{KE}>25$ using synthetic rainfall series for several locations in Espírito Santo State, Brazil; b) developing ANNs to spatially interpolate rainfall erosivity in Espírito Santo State, Brazil; and c) comparing the developed ANNs performance to other spatial interpolators.

\section{MATERIALS AND METHODS}

ASSESSING RAINFALL EROSIVITY INDEXES

The stochastic weather generator ClimaBR 2.0, developed by Baena et al. (2005) and validated by Zanetti et al. (2006), was used to generate daily synthetic rainfall series for 73 pluviometric stations in Espírito Santo State (Figure 1). Oliveira et al. (2005a, b) describe all the method to generate synthetic rainfall precipitation series. The input data used to generate each synthetic rainfall series were the measured daily rainfall depth data series in the standardized format of the Brazilian National Water Agency (http://hidroweb.ana.gov.br) with 15 or more years in extension. Each synthetic rainfall series had 100-year daily data of: rainfall depth, storm duration, peak storm intensity, time to peak and storm profile patterns.

A computational algorithm was developed to identify all the erosive precipitations on each rainfall series. The erosive precipitations were taken as all rainfall with depth equal or higher than $10 \mathrm{~mm}$ or lower than $10 \mathrm{~mm}$ in depth, but with a 15 minute depth equal or higher than $6 \mathrm{~mm}$ (Wischmeier and Smith 1958, Wischmeier 1959, Cabeda 1976). Two different rainfall erosivity indices were computed $\left(\mathrm{EI}_{30}\right.$ and $\left.\mathrm{KE}>25\right)$ using two different equations to calculate erosive precipitation kinetic energy (KE).

Before the calculation of $\mathrm{EI}_{30}$ (Wischmeier and Smith 1958) and KE $>25$ (Hudson 1973) indices, it was necessary to estimate the erosive precipitation kinetic energy (KE). KE values were computed individually by the equations proposed by Wischmeier and Smith (1958) (equation 1) and Wagner and Massambani (1988) (equation 2). 


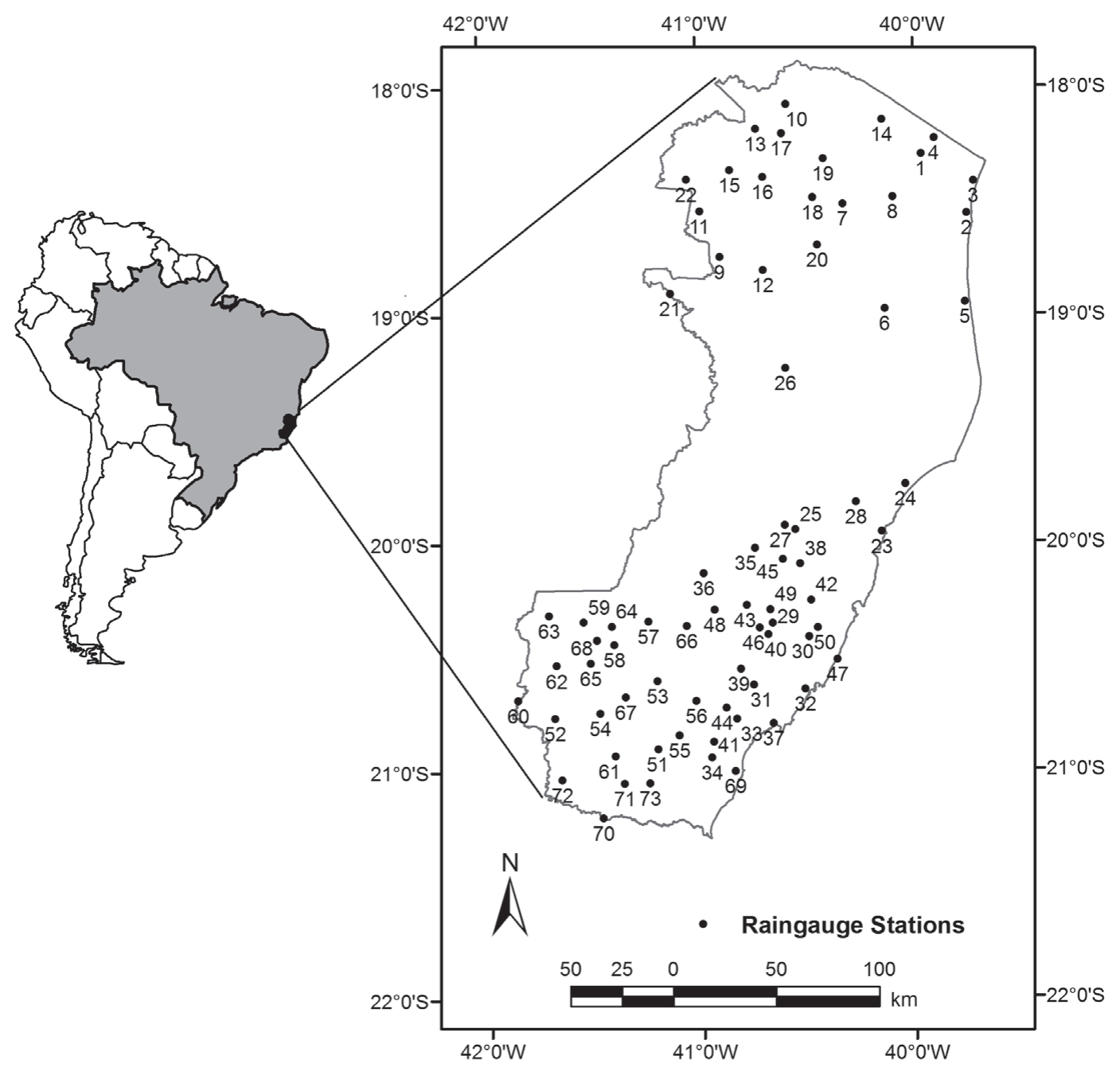

Figure 1 - Pluviometric stations in Espírito Santo State where synthetic rainfall series were generated.

Equation 1 is an universal accepted equation and Equation 2 is a local equation proposed to São Paulo State (Brazil). The two equations were used intending to make a comparison between their results on rainfall erosivity indices values.

$\mathrm{KE}=0.119+0.0873 \log \mathrm{I}$

$\mathrm{KE}=0.153+0.0645 \log \mathrm{I}$

where:

$$
\begin{array}{ll}
\mathrm{KE} & =\text { kinetic energy, } \mathrm{MJ} \cdot \mathrm{ha}^{-1} \cdot \mathrm{mm}^{-1} \text {; and } \\
\mathrm{I} & =\text { rainfall intensity, } \mathrm{mm} \cdot \mathrm{h}^{-1} .
\end{array}
$$

Equations 1 and 2 were used to compute KE of all the erosive rainfall with intensity equal to or lower than $76 \mathrm{~mm} \cdot \mathrm{h}^{-1}$. Erosive rainfall with greater intensities were assumed to have a $\mathrm{KE}$ equal

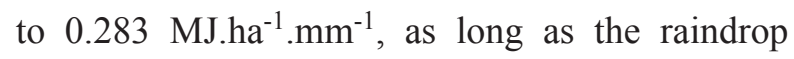
diameter does not rise up to rainfall intensities greater than this limit (Foster et al. 1981).

The $\mathrm{EI}_{30}$ parameter for each specific event was calculated as the product of total kinetic energy (KE) computed individually by equations 1 and 2 and the maximum $30 \mathrm{~min}$ intensity, according to Wischmeier and Smith (1958). The total KE of each event was computed using the one minute time step. Monthly values were determined as the sum of the individual events determined through the $\mathrm{EI}_{30}$ parameter $\left(\mathrm{MJ} \cdot \mathrm{mm} \cdot \mathrm{ha}^{-1} \cdot \mathrm{h}^{-1}\right)$, and annual 
values were determined in the same manner. Then mean monthly and annual values were computed using the 100-year values.

The KE $>25$ parameter for each specific event was calculated as the product of total kinetic energy (KE) computed individually by equations 1 and 2 and rainfall depth, according to Hudson (1973). The total KE of each event was computed by using one minute time step. Only rainfall intensities greater than $25 \mathrm{~mm} . \mathrm{h}^{-1}$ were considered. Monthly values were determined as the sum of the individual events determined by the KE $>25$ parameter $\left(\mathrm{MJ} \cdot \mathrm{ha}^{-1}\right)$ and annual values were determined in the same manner. Later mean monthly and annual values were computed using the 100 -year values.

Since two different equations were used to compute KE (Wischmeier and Smith 1958, Wagner and Massambani 1988) and two different erosivity indices were calculated $\left(\mathrm{EI}_{30}\right.$ and $\left.\mathrm{KE}>25\right)$, final results consisted on four monthly and four annual values of $\mathrm{R}$ factors for each pluviometric station.

\section{DEVELOPMENT OF ANNS TO SPATIALLY INTERPOLATE}

\section{RAINFALL EROSIVITY INDICES}

Neural modeling was carried out with MathWorks MatLab ${ }^{\circledR}$ software (MATLAB 2000). Pluviometric stations $\mathrm{R}$ values were randomly divided in two sub data-sets to develop 48 ANNs (four monthly R indices for 12 months): training sub data-set (60 stations) and test sub data-set (13 stations).

In the present study, a four-layer ANN model was used. The ANN architecture was $3-n_{1}-n_{2}-1$ type, corresponding to one input layer with three variables (input parameters), two intermediate layers with $\mathrm{n}_{1}$ and $\mathrm{n}_{2}$ neurons and one neuron at the output layer representing output variable. The input variables were composed of the latitude and longitude values of each station (decimal degrees) and the altitude value (meters). A linear activation function was used in the output layer to obtain the rainfall erosivity value ( $\mathrm{R}$ factor), in $\mathrm{MJ} . \mathrm{mm} \cdot \mathrm{h}^{-1}$. $\mathrm{ha}^{-1}$.year ${ }^{-1}\left(\mathrm{EI}_{30}\right)$ or MJ.ha ${ }^{-1}$.year ${ }^{-1}(\mathrm{KE}>25)$.
Before ANN's training all input and output data sets were standardized to values between -1 and 1. This procedure is essential to guarantee better training efficiency (Maier and Dandy 2000). The training algorithm feed forward back propagation was used. After each algorithm interaction the ANN's free parameters were refined by the Levenberg-Marquardt training rule. Different numbers of neurons at intermediate layers were tested ( $n_{1}$ and $n_{2}$ varying from 1 to 12 neurons) as well as different total training epochs (50, 100, 200 and 500 epochs). The ANN's total number of neurons were limited by the number of samples (stations) used on the training sub dataset as suggested by Hagan et al. (1996).

Considering that at the beginning of the ANN's training the free parameters are randomly generated, the ANNs resulted from each combination of $\mathrm{n}_{1}$ and $\mathrm{n}_{2}$ and training seasons were trained 20 times. For each month and each one of the four R factors, the ANNs that presented the highest correlation coefficient ( $r$ ) obtained in the test sub data-set were selected to be the spatial interpolator ANNs.

The ANNs to spatially interpolate the annual $\mathrm{R}$ factor were not developed because their values were computed by the sum of the ANN's monthly interpolated $\mathrm{R}$ factors.

\section{EVALUATION OF ANN AND OTHER SPATIAL INTERPOLATOR} PERFORMANCES

Aside from the selected ANN spatial interpolators, the following interpolators were evaluated: inverse distance weighted (IDW) - considering weights 2 (IDW2) and 3 (IDW3); and universal kriging - considering spherical (KSPH) and exponential (KEXP) semivariogram models.

Interpolators' evaluation was done using the cross-validation method (Robinson and Metternicht 2006). For each station, observed (Oi) and interpolated $(\mathrm{Si}) \mathrm{R}$ values were used to compute the agreement index (d) (Willmont 1981): 


$$
\mathrm{d}=1-\frac{\sum_{\mathrm{i}=1}^{\mathrm{J}}\left(\mathrm{O}_{\mathrm{i}}-\mathrm{S}_{\mathrm{i}}\right)^{2}}{\left.\sum_{\mathrm{i}=1}^{\mathrm{J}}\left|\mathrm{S}_{\mathrm{i}}-\overline{\mathrm{O}}\right|+\mathrm{O}_{\mathrm{i}}-\overline{\mathrm{O}} \mid\right)^{2}}
$$

where:

$$
\begin{array}{ll}
\mathrm{d}= & \text { agreement index; } \\
\mathrm{O}= & \text { observed } \mathrm{R} \text { factor value; } \\
\mathrm{S}= & \text { observed } \mathrm{R} \text { factor value; and } \\
\overline{\mathrm{O}}= & \text { mean observed } \mathrm{R} \text { factor value. }
\end{array}
$$

\section{RESULTS AND DISCUSSION}

\section{RAINFALL EROSIVITY INDEX VALUES}

Table I presents the 73 values of mean annual $\mathrm{EI}_{30}$ and $\mathrm{KE}>25$ rainfall erosivity indices computed by both equations to calculate rainfall kinetic energy:
WS (equation 1 by Wischmeier and Smith 1958) and WM (equation 2 by Wagner and Massambani 1988). It can be observed that $\mathrm{EI}_{30}$ index computed by the use of WM equation are about 3.0\% higher than those computed by WS equation. On the other hand, KE $>25$ index values computed by WS equation are $1.1 \%$ higher than those computed by WM equation. According to Gonçalves et al. (2006) this occurs only with KE $>25$ index, because the WS equation computes higher KE values when rainfall intensities are greater than $31 \mathrm{~mm} \cdot \mathrm{h}^{-1}$. The highest observed difference is equal to $6.2 \%$ on $\mathrm{EI}_{30}$ and $16.7 \%$ on $\mathrm{KE}>25$, both at Santo Agostinho pluviometric station.

\begin{tabular}{|c|c|c|c|c|c|c|c|c|c|}
\hline \multirow[t]{2}{*}{ Number } & \multirow[t]{2}{*}{ Station } & \multirow[t]{2}{*}{ Lat. $\left({ }^{\circ}\right)$} & \multirow[t]{2}{*}{ Long. $\left({ }^{\circ}\right)$} & \multicolumn{3}{|c|}{$\begin{array}{c}\text { EI }_{30} \\
\left(M J . m m \cdot h^{-1} \cdot h^{-1} \cdot \text { year }^{-1}\right)\end{array}$} & \multicolumn{3}{|c|}{$\begin{array}{c}\text { KE }>25 \\
\left(\text { MJ.ha }^{-1} \text {.year }^{-1}\right)\end{array}$} \\
\hline & & & & WS & WM & Dif. (\%) & WS & WM & Dif. (\%) \\
\hline 1 & Morro D'anta (Pedro Canário) & -18.30 & -39.96 & 2,696 & 2,780 & 3.1 & 27 & 27 & 0.0 \\
\hline 2 & Conceição da Barra & -18.56 & -39.75 & 5,675 & 5,843 & 3.0 & 57 & 56 & 1.8 \\
\hline 3 & Fazenda Viração & -18.42 & -39.72 & 4,952 & 5,113 & 3.3 & 50 & 49 & 2.0 \\
\hline 4 & Fazenda Klabin & -18.23 & -39.90 & 5,038 & 5,212 & 3.5 & 49 & 49 & 0.0 \\
\hline 5 & Barra Nova & -18.95 & -39.76 & 6,944 & 7,133 & 2.7 & 71 & 71 & 0.0 \\
\hline 6 & Barra Seca & -18.98 & -40.13 & 4,968 & 5,110 & 2.9 & 52 & 51 & 1.9 \\
\hline 7 & Fazenda Alegria & -18.52 & -40.32 & 4,888 & 5,016 & 2.6 & 52 & 51 & 1.9 \\
\hline 8 & Itauninhas & -18.49 & -40.09 & 4,501 & 4,639 & 3.1 & 47 & 46 & 2.1 \\
\hline 9 & Barra de São francisco & -18.75 & -40.89 & 4,029 & 4,145 & 2.9 & 43 & 42 & 2.3 \\
\hline 10 & Mucurici & -18.08 & -40.58 & 5,559 & 5,704 & 2.6 & 59 & 58 & 1.7 \\
\hline 11 & Água Doce & -18.55 & -40.98 & 5,248 & 5,398 & 2.9 & 56 & 55 & 1.8 \\
\hline 12 & Cedrolândia & -18.81 & -40.69 & 4,613 & 4,745 & 2.9 & 49 & 49 & 0.0 \\
\hline 13 & Cotaxe & -18.19 & -40.72 & 5,176 & 5,320 & 2.8 & 54 & 54 & 0.0 \\
\hline 14 & Fazenda Limoeiro & -18.15 & -40.14 & 4,548 & 4,686 & 3.0 & 47 & 47 & 0.0 \\
\hline 15 & Ecoporanga & -18.37 & -40.84 & 4,324 & 4,449 & 2.9 & 45 & 45 & 0.0 \\
\hline 16 & Joaçuba & -18.40 & -40.69 & 6,434 & 6,602 & 2.6 & 69 & 69 & 0.0 \\
\hline 17 & Patrimônio Santa Luzia do Norte & -18.21 & -40.60 & 4,571 & 4,697 & 2.8 & 49 & 48 & 2.0 \\
\hline 18 & Patrimônio XV & -18.49 & -40.46 & 5,021 & 5,158 & 2.7 & 52 & 52 & 0.0 \\
\hline 19 & São João do Sobrado & -18.32 & -40.41 & 3,729 & 3,832 & 2.8 & 40 & 40 & 0.0 \\
\hline 20 & Córrego da Boa Esperança & -18.70 & -40.44 & 4,652 & 4,786 & 2.9 & 47 & 47 & 0.0 \\
\hline
\end{tabular}

TABLE I

Mean annual rainfall erosivity indices $\mathrm{EI}_{30}$ and $\mathrm{KE}>\mathbf{2 5}$ computed by kinectic energy equations presented by Wischmeier and Smith (1958) (WS) and Wagner and Massambani (1988) (WM) at pluviometric stations of Espírito Santo State.

Dif. $=$ percentage difference of the values computed for each index. 
TABLE I (CONTINUATION)

\begin{tabular}{|c|c|c|c|c|c|c|c|c|c|}
\hline \multirow[t]{2}{*}{ Number } & \multirow[t]{2}{*}{ Station } & \multirow[t]{2}{*}{ Lat. $\left({ }^{\circ}\right)$} & \multirow[t]{2}{*}{ Long. $\left({ }^{\circ}\right)$} & \multicolumn{3}{|c|}{$\begin{array}{c}\text { EI }_{30} \\
\left(\mathrm{MJ} . \mathrm{mm} \cdot \mathrm{h}^{-1} \cdot \mathrm{ha}^{-1} \cdot \text { year }^{-1}\right)\end{array}$} & \multicolumn{3}{|c|}{$\begin{array}{c}\text { KE }>25 \\
\left(M_{J} \cdot \text { ha }^{-1} \cdot \text { year }^{-1}\right) \\
\end{array}$} \\
\hline & & & & WS & WM & Dif. (\%) & WS & WM & Dif. (\%) \\
\hline 21 & Mantenópolis & -18.91 & -41.12 & 5,097 & 5,235 & 2.7 & 56 & 55 & 1.8 \\
\hline 22 & Santo Agostinho & -18.41 & -41.04 & 2,123 & 2,254 & 6.2 & 6 & 5 & 16.7 \\
\hline 23 & Santa Cruz - litoral & -19.96 & -40.15 & 4,541 & 4,681 & 3.1 & 47 & 46 & 2.1 \\
\hline 24 & Riacho & -19.75 & -40.04 & 5,051 & 5,212 & 3.2 & 52 & 51 & 1.9 \\
\hline 25 & Valsugana Velha - montante & -19.95 & -40.55 & 8,560 & 8,810 & 2.9 & 88 & 87 & 1.1 \\
\hline 26 & Novo Brasil & -19.24 & -40.59 & 5,493 & 5,646 & 2.8 & 57 & 57 & 0.0 \\
\hline 27 & Santa Tereza - Museu de Biologia & -19.93 & -40.60 & 5,138 & 5,302 & 3.2 & 53 & 52 & 1.9 \\
\hline 28 & Aracruz & -19.83 & -40.27 & 4,914 & 5,070 & 3.2 & 49 & 49 & 0.0 \\
\hline 29 & Domingos Martins (DNOS) & -20.36 & -40.66 & 6,928 & 7,151 & 3.2 & 70 & 69 & 1.4 \\
\hline 30 & Fazenda Jucuruaba & -20.42 & -40.49 & 5,863 & 6,027 & 2.8 & 62 & 61 & 1.6 \\
\hline 31 & Alfredo Chaves (DNOS) & -20.63 & -40.75 & 7,795 & 8,004 & 2.7 & 82 & 81 & 1.2 \\
\hline 32 & Guarapari (DNOS) & -20.65 & -40.51 & 4,492 & 4,620 & 2.8 & 45 & 45 & 0.0 \\
\hline 33 & Iconha - montante & -20.78 & -40.83 & 7,506 & 7,708 & 2.7 & 78 & 77 & 1.3 \\
\hline 34 & Usina Paineiras (DNOS) & -20.95 & -40.95 & 5,006 & 5,167 & 3.2 & 51 & 50 & 2.0 \\
\hline 35 & Santa Maria do Jetibá (DNOS) & -20.03 & -40.74 & 5,484 & 5,632 & 2.7 & 59 & 58 & 1.7 \\
\hline 36 & Garrafão (DNOS) & -20.14 & -40.98 & 3,979 & 4,095 & 2.9 & 43 & 42 & 2.3 \\
\hline 37 & Anchieta (DNOS) & -20.80 & -40.66 & 4,992 & 5,146 & 3.1 & 49 & 49 & 0.0 \\
\hline 38 & Santa Leopoldina (DNOS) & -20.10 & -40.53 & 6,144 & 6,322 & 2.9 & 62 & 62 & 0.0 \\
\hline 39 & Matilde (DNOS) & -20.56 & -40.81 & 8,357 & 8,598 & 2.9 & 2.9 & 87 & 1.1 \\
\hline 40 & Marechal Floriano (DNOS) & -20.41 & -40.68 & 6,625 & 6,821 & 3.0 & 3.0 & 69 & 0.0 \\
\hline 41 & Rio Novo do Sul (DNOS) & -20.88 & -40.94 & 7,657 & 7,867 & 2.7 & 2.7 & 78 & 0.0 \\
\hline 42 & Duas Bocas (DNOS) & -20.26 & -40.48 & 3,892 & 3,988 & 2.5 & 2.5 & 40 & 0.0 \\
\hline 43 & Perobinha (DNOS) & -20.28 & -40.78 & 3,986 & 4,120 & 3.4 & 3.4 & 41 & 0.0 \\
\hline 44 & Duas Barras (DNOS) & -20.73 & -40.88 & 8,107 & 8,325 & 2.7 & 2.7 & 82 & 1.2 \\
\hline 45 & Cachoeira Suiça (DNOS) & -20.08 & -40.61 & 5,687 & 5,867 & 3.2 & 3.2 & 58 & 0.0 \\
\hline 46 & Granja São Jerônimo (DNOS) & -20.38 & -40.72 & 6,222 & 6,412 & 3.1 & 3.1 & 64 & 1.5 \\
\hline 47 & Ponta da Fruta & -20.52 & -40.36 & 4,335 & 4,480 & 3.3 & 3.3 & 42 & 2.3 \\
\hline 48 & São Rafael & -20.30 & -40.93 & 3,420 & 3,535 & 3.4 & 3.4 & 34 & 2.9 \\
\hline 49 & Córrego do Galo (DNOS) & -20.30 & -40.67 & 5,061 & 5,235 & 3.4 & 3.4 & 51 & 0.0 \\
\hline 50 & Canaã & -20.38 & -40.45 & 6,167 & 6,332 & 2.7 & 2.7 & 63 & 1.6 \\
\hline 51 & Atílio Vivacqua & -20.91 & -41.20 & 4,955 & 5,099 & 2.9 & 2.9 & 52 & 0.0 \\
\hline 52 & Guaçuí & -20.77 & -41.68 & 6,592 & 6,785 & 2.9 & 2.9 & 69 & 0.0 \\
\hline 53 & Castelo & -20.61 & -41.20 & 5,649 & 5,816 & 3.0 & 3.0 & 59 & 1.7 \\
\hline 54 & Rive & -20.75 & -41.47 & 6,584 & 6,773 & 2.9 & 2.9 & 69 & 1.4 \\
\hline 55 & Cachoeiro do Itapemirim (DNOS) & -20.85 & -41.10 & 4,657 & 4,801 & 3.1 & 3.1 & 47 & 2.1 \\
\hline 56 & Jacigua (DNOS) & -20.70 & -41.02 & 7,055 & 7,262 & 2.9 & 2.9 & 72 & 1.4 \\
\hline 57 & Conceição do Castelo (DNOS) & -20.35 & -41.24 & 5,374 & 5,527 & 2.8 & 2.8 & 57 & 0.0 \\
\hline 58 & Muniz Freire (DNOS) & -20.45 & -41.40 & 6,608 & 6,803 & 3.0 & 3.0 & 70 & 0.0 \\
\hline
\end{tabular}

Dif. $=$ percentage difference of the values computed for each index. 
TABLE I (CONTINUATION)

\begin{tabular}{|c|c|c|c|c|c|c|c|c|c|}
\hline \multirow[t]{2}{*}{ Number } & \multirow[t]{2}{*}{ Station } & \multirow[t]{2}{*}{ Lat. $\left({ }^{\circ}\right)$} & \multirow[t]{2}{*}{ Long. $\left({ }^{\circ}\right)$} & \multicolumn{3}{|c|}{$\begin{array}{c}\text { EI }_{30} \\
\left(\mathrm{MJ} . \mathrm{mm} \cdot \mathrm{h}^{-1} \cdot \mathrm{ha}^{-1} \cdot \mathrm{year}^{-1}\right)\end{array}$} & \multicolumn{3}{|c|}{$\begin{array}{c}\text { KE }>25 \\
\left(\text { MJ.ha }^{-1} \cdot \text { year }^{-1}\right)\end{array}$} \\
\hline & & & & WS & WM & Dif. (\%) & WS & $\mathbf{W M}$ & Dif. (\%) \\
\hline 59 & Iuna & -20.35 & -41.54 & 5,099 & 5,247 & 2.9 & 2.9 & 53 & 1.9 \\
\hline 60 & Dores do Rio Preto & -20.69 & -41.85 & 5,890 & 6,061 & 2.9 & 2.9 & 62 & 1.6 \\
\hline 61 & Fazenda Monte Alegre (DNOS) & -20.94 & -41.40 & 6,067 & 6,250 & 3.0 & 3.0 & 63 & 1.6 \\
\hline 62 & Ibitirama (DNOS) & -20.54 & -41.67 & 7,121 & 7,326 & 2.9 & 2.9 & 75 & 1.3 \\
\hline 63 & Santa Cruz - Caparão (DNOS) & -20.32 & -41.70 & 6,732 & 6,929 & 2.9 & 2.9 & 71 & 0.0 \\
\hline 64 & Usina Fortaleza (DNOS) & -20.37 & -41.41 & 6,632 & 6,823 & 2.9 & 2.9 & 71 & 0.0 \\
\hline 65 & Itaici & -20.53 & -41.51 & 6,564 & 6,751 & 2.8 & 2.8 & 70 & 0.0 \\
\hline 66 & Arace (DNOS) & -20.37 & -41.06 & 5,939 & 6,108 & 2.8 & 2.8 & 64 & 0.0 \\
\hline 67 & Burarama (DNOS) & -20.68 & -41.35 & 9,643 & 9,885 & 2.5 & 2.5 & 104 & 1.0 \\
\hline 68 & Terra Corrida (DNOS) & -20.43 & -41.48 & 7,010 & 7,212 & 2.9 & 2.9 & 75 & 0.0 \\
\hline 69 & Barra do Itapemirim (DNOS) & -21.01 & -40.84 & 2,713 & 2,805 & 3.4 & 3.4 & 26 & 0.0 \\
\hline 70 & Ponte de Itabapoana & -21.21 & -41.46 & 5,085 & 5,229 & 2.8 & 2.8 & 53 & 1.9 \\
\hline 71 & Mimoso do Sul (DNOS) & -21.06 & -41.36 & 6,244 & 6,419 & 2.8 & 2.8 & 65 & 0.0 \\
\hline 72 & São José do Calçado & -21.04 & -41.65 & 6,600 & 6,782 & 2.8 & 2.8 & 70 & 1.4 \\
\hline \multirow[t]{2}{*}{73} & São José das Torres & -21.06 & -41.24 & 7,246 & 7,450 & 2.8 & 2.8 & 74 & 1.3 \\
\hline & AVERAGE & - & - & - & - & 3.0 & - & - & 1.1 \\
\hline
\end{tabular}

Dif. $=$ percentage difference of the values computed for each index.

The low values of percentage differences on Table I indicate that both WS and WM equations compute very similar values to both $\mathrm{R}$ indices in Espírito Santo State. Gonçalves et al. (2006) had found the same result in Rio de Janeiro, a state limiting with Espírito Santo and located on a homogeneous area according to similarity of rainfall distribution (Keller Filho et al. 2005). This was also observed in other homogeneous rainfall areas in Brazil, like the Brazilian Savanna (Marques et al. 1997, Silva et al. 1997).

The $\mathrm{EI}_{30}$ index ranged from 2,123 (Santo Agostinho station) to $9,885 \mathrm{MJ} \cdot \mathrm{mm} \cdot \mathrm{ha}^{-1} \cdot \mathrm{h}^{-1}$. year $^{-1}$ (Burarama (DNOS)). The KE $>25$ index ranged from 5.0 to 105.0 MJ.ha-1.year-1 on the same stations. The lowest $\mathrm{R}$ index values were observed at higher latitudes, where annual pluviometric depths are also the lowest. On the other hand, the higher values were observed on lower latitudes and higher longitudes (near the Brazilian coast), in regions characterized by orographic precipitations and maritime influence (Castro et al. 2010). Silva et al. (2010c) had used pluviometric data of Espírito Santo to calculate $\mathrm{EI}_{30}$ indices and had found values ranging from 5,091 to $7,958 \mathrm{MJ} \cdot \mathrm{mm} \cdot \mathrm{ha}^{-1} \cdot \mathrm{h}^{-1} \cdot \mathrm{year}^{-1}$.

Average $\mathrm{EI}_{30}$ e $\mathrm{KE}>25$ were 5,592 MJ.mm.ha1.h ${ }^{-1}$.year ${ }^{-1}$ and 58.0 MJ.ha' ${ }^{-1}$.year ${ }^{-1}$, respectively. These values are very close to those found by Carvalho et al. (2005) and Gonçalves et al. (2006) in Rio de Janeiro, located on a homogeneous area according to the similarity of rainfall distribution (Keller Filho et al. 2005).

The $\mathrm{EI}_{30}$ values on the west side of Espírito Santo (lower longitudes) were close to those found by Mello et al. (2007) near the limit to the State of Minas Gerais. It indicates the applicability of the use of synthetic rainfall series to estimate the $\mathrm{R}$ factor, corroborating Zhang et al. (2010).

In Espírito Santo State there is one value of $\mathrm{EI}_{30}$ calculated by using pluviographic data from 1998 to 2003 on Aracruz station. This value is 
equal to 6,500 MJ.mm.ha ${ }^{-1} \cdot h^{-1} \cdot$ year $^{-1}$ (Martins et al. 2010) and is relatively close to the one found on the present paper (about 5,000 MJ.mm.ha ${ }^{-1} \cdot \mathrm{h}^{-1} \cdot$ year $^{-1}$ ), once again indicating the applicability of the use of synthetic rainfall series to estimate the $\mathrm{R}$ factor.

\section{ANNS DEVELOPED TO SPATIALLY INTERPOLATE}

\section{RAINFALL EROSIVITY INDICES}

Table II presents the architecture (number of neurons on the intermediate layers and training seasons) of the ANNs developed to spatially interpolate monthly values of $\mathrm{EI}_{30}$ and $\mathrm{KE}>25$ at Espírito Santo State, considering WS and WM equations. According to the criteria taken from Hagan et al.
(1996), the maximum number of neurons on the intermediate layers of the ANNs would be 12 . The low number of neurons on the developed ANNs (Table II) indicates a lower complexity, better ability to generalization and estimation (Bernardos and Vosniakos 2007) and had a lower probability of "memorizing" answers (Sinha and Wang 2007).

ANN with increased numbers of neurons were only those for the spatial interpolation of $\mathrm{EI}_{30}$ for the months of October, November and December (KE computed by WS equation) and for February and October (KE computed by WM equation). The same happened to the ANNs developed for spatial interpolation of KE $>25$ for May (KE computed by WM equation).

TABLE II

Number of neurons on intermediate layers and training seasons of the ANN developed to spatial interpolation of monthly $\mathrm{EI}_{30}$ e KE>25 erosivity indices (computed considering WS and WM equations) at Espírito Santo.

\begin{tabular}{|c|c|c|c|c|c|c|c|c|c|c|c|c|}
\hline \multirow{3}{*}{ MONTH } & \multicolumn{6}{|c|}{$\mathbf{E I}_{30}$} & \multicolumn{6}{|c|}{$K E>25$} \\
\hline & \multicolumn{3}{|c|}{$\mathbf{F}$} & \multicolumn{3}{|c|}{ WM } & \multicolumn{3}{|c|}{$\mathbf{F}$} & \multicolumn{3}{|c|}{ WM } \\
\hline & $\mathrm{n}_{1}$ & $n_{2}$ & seasons & $\mathbf{n}_{1}$ & $\mathbf{n}_{2}$ & seasons & $n_{1}$ & $n_{2}$ & seasons & $n_{1}$ & $\mathbf{n}_{2}$ & seasons \\
\hline Jan. & 1 & 4 & 50 & 3 & 2 & 100 & 4 & 4 & 200 & 4 & 5 & 200 \\
\hline Feb. & 2 & 3 & 50 & 5 & 6 & 200 & 4 & 2 & 500 & 1 & 6 & 100 \\
\hline Mar. & 3 & 2 & 50 & 5 & 4 & 100 & 2 & 4 & 200 & 3 & 3 & 50 \\
\hline Apr. & 3 & 3 & 500 & 3 & 2 & 200 & 2 & 6 & 100 & 4 & 5 & 200 \\
\hline May & 4 & 3 & 200 & 6 & 1 & 200 & 2 & 6 & 200 & 6 & 5 & 500 \\
\hline Jun. & 6 & 3 & 100 & 2 & 3 & 500 & 4 & 1 & 500 & 6 & 3 & 500 \\
\hline Jul. & 2 & 4 & 50 & 4 & 4 & 50 & 1 & 5 & 200 & 4 & 2 & 50 \\
\hline Aug. & 1 & 6 & 100 & 6 & 4 & 500 & 6 & 2 & 500 & 6 & 1 & 200 \\
\hline Sep. & 3 & 5 & 100 & 4 & 2 & 200 & 4 & 3 & 500 & 4 & 2 & 200 \\
\hline Oct. & 6 & 5 & 500 & 5 & 6 & 100 & 1 & 3 & 100 & 3 & 3 & 200 \\
\hline Nov. & 6 & 5 & 500 & 4 & 2 & 200 & 3 & 5 & 50 & 2 & 4 & 100 \\
\hline Dec. & 5 & 6 & 500 & 3 & 2 & 500 & 4 & 1 & 50 & 3 & 3 & 500 \\
\hline
\end{tabular}

\section{EVALUATION OF ANN AND OTHER SPATIAL}

INTERPOLATORS' PERFORMANCE

Table III presents the agreement index (d) used to evaluate the ability of the interpolators to estimate spatially $\mathrm{KE}>25$ and $\mathrm{EI}_{30}$ erosivity indices. Considering each erosivity index separately $\left(\mathrm{EI}_{30}\right.$ and $\mathrm{KE}>25$ ), the values of " $\mathrm{d}$ " for conventional interpolators (IDW and kriging) are very similar for each month. Thus the performance of conventional interpolators doesn't depend on the equation taken to compute KE (WS or WM). This behavior was expected since, as previously shown in this paper, WS and WM equations compute very similar values to both $\mathrm{R}$ indices for Espírito Santo State. Thus, the performance of conventional 
interpolators only depends on the distance between stations, which are weighting factors in mathematical models used for conventional interpolation. This did not occur on the ANNs because trained architectures (Table II) are different for each month and each situation (WS or WM equations), resulting in different performances.
In general, the conventional interpolation methods evaluated had similar performances. These interpolators have advantages and disadvantages that depend on various factors such as the amount of data available and regularity of the spatial distribution. If the distribution of observed data is not favorable, the results may be unsatisfactory.

TABLE III

Agreement index (d) used to evaluate the ability of the interpolators to estimate spatial $\mathrm{KE}>25 \mathrm{e}$ $\mathrm{EI}_{30}$ erosivity indexes (computed considering WS and WM equations) at Espírito Santo.

\begin{tabular}{|c|c|c|c|c|c|c|}
\hline \multirow{2}{*}{ Erosivity index } & \multirow{2}{*}{ Period } & \multicolumn{5}{|c|}{ d } \\
\hline & & ANN & IDW2 & IDW3 & KSPH & KEXP \\
\hline \multirow{13}{*}{$\mathrm{EI}_{30}(\mathrm{WS})$} & Jan. & 0.53 & 0.52 & 0.54 & 0.52 & 0.54 \\
\hline & Feb. & 0.85 & 0.69 & 0.74 & 0.75 & 0.72 \\
\hline & Mar. & 0.84 & 0.67 & 0.69 & 0.69 & 0.68 \\
\hline & Apr. & 0.94 & 0.75 & 0.75 & 0.77 & 0.78 \\
\hline & May & 0.90 & 0.76 & 0.78 & 0.78 & 0.78 \\
\hline & Jun. & 0.55 & 0.75 & 0.74 & 0.76 & 0.76 \\
\hline & Jul. & 0.92 & 0.51 & 0.51 & 0.52 & 0.52 \\
\hline & Aug. & 0.88 & 0.61 & 0.60 & 0.65 & 0.65 \\
\hline & Sep. & 0.96 & 0.65 & 0.65 & 0.69 & 0.69 \\
\hline & Oct. & 0.54 & 0.45 & 0.44 & 0.47 & 0.47 \\
\hline & Nov. & 0.82 & 0.41 & 0.39 & 0.43 & 0.44 \\
\hline & Dec. & 0.77 & 0.69 & 0.69 & 0.69 & 0.69 \\
\hline & Year & 0.86 & 0.66 & 0.65 & 0.68 & 0.69 \\
\hline \multirow{13}{*}{$\mathbf{E I}_{30}(\mathbf{W M})$} & Jan. & 0.83 & 0.52 & 0.54 & 0.52 & 0.55 \\
\hline & Feb. & 0.85 & 0.70 & 0.74 & 0.76 & 0.73 \\
\hline & Mar. & 0.91 & 0.67 & 0.69 & 0.69 & 0.68 \\
\hline & Apr. & 0.94 & 0.75 & 0.75 & 0.77 & 0.78 \\
\hline & May & 0.92 & 0.76 & 0.78 & 0.78 & 0.78 \\
\hline & Jun. & 0.83 & 0.75 & 0.74 & 0.76 & 0.76 \\
\hline & Jul. & 0.95 & 0.52 & 0.51 & 0.53 & 0.53 \\
\hline & Aug. & 0.79 & 0.61 & 0.60 & 0.65 & 0.65 \\
\hline & Sep. & 0.87 & 0.66 & 0.65 & 0.69 & 0.69 \\
\hline & Oct. & 0.84 & 0.45 & 0.44 & 0.47 & 0.47 \\
\hline & Nov. & 0.66 & 0.41 & 0.39 & 0.43 & 0.44 \\
\hline & Dec. & 0.73 & 0.69 & 0.69 & 0.69 & 0.69 \\
\hline & Year & 0.86 & 0.66 & 0.65 & 0.68 & 0.69 \\
\hline \multirow{4}{*}{$\mathrm{KE}>25(\mathrm{WS})$} & Jan. & 0.92 & 0.48 & 0.50 & 0.47 & 0.50 \\
\hline & Feb. & 0.85 & 0.69 & 0.72 & 0.73 & 0.70 \\
\hline & Mar. & 0.64 & 0.65 & 0.67 & 0.67 & 0.65 \\
\hline & Apr. & 0.94 & 0.75 & 0.75 & 0.77 & 0.77 \\
\hline
\end{tabular}


TABLE III (CONTINUATION)

\begin{tabular}{lcccccc}
\hline \multirow{2}{*}{ Erosivity index } & Period & \multicolumn{5}{c}{ d } \\
\cline { 3 - 7 } & & ANN & IDW2 & IDW3 & KSPH & KEXP \\
\hline \multirow{6}{*}{ KE>25 (WS) } & May & 0.85 & 0.75 & 0.75 & 0.76 & 0.77 \\
& Jun. & 0.61 & 0.73 & 0.72 & 0.74 & 0.74 \\
& Jul. & 0.38 & 0.10 & 0.10 & 0.11 & 0.11 \\
& Aug. & 0.96 & 0.78 & 0.78 & 0.80 & 0.80 \\
& Sep. & 0.95 & 0.52 & 0.52 & 0.53 & 0.54 \\
& Oct. & 0.76 & 0.45 & 0.44 & 0.48 & 0.49 \\
& Nov. & 0.80 & 0.39 & 0.38 & 0.42 & 0.42 \\
& Dec. & 0.88 & 0.70 & 0.70 & 0.70 & 0.70 \\
& Year & 0.85 & 0.67 & 0.67 & 0.70 & 0.70 \\
\hline
\end{tabular}

Table III data shows that "d" index was higher on 44 of the 48 developed ANNs, which indicates better performance of ANNs for spatial interpolation of the $\mathrm{R}$ factor compared to conventional interpolators, as also seen by Moreira et al. $(2006,2009)$ in the States of São Paulo and Minas Gerais, respectively. According to Akkala et al. (2010), ANN interpolators work well with sparse data irregularly distributed, just as for the data presented (Figure 1). The ANNs, in order to have better performance, need consistent training and the data-set used must represent the nuances of the terrain to be modeled (Teegavarapu 2007, Miranda et al. 2009, Sivapragasam et al. 2010), as was the case in this study.

Another important factor that led to the superiority of ANNs consisted in considering the altitude to interpolate the R factor (Goovaerts 1999, Moreira et al. 2006, Silva et al. 2010b). This is a very important variable to explain the behavior of precipitation, especially in regions of great orographic influence on the climate, as for Espírito Santo State (Keller Filho et al. 2005; Melo Júnior et al. 2006).

The ANNs developed to spatially interpolate $\mathrm{EI}_{30}$ and $\mathrm{KE}>25$ indices with $\mathrm{KE}$ computed by the use of WM equation showed always better performance than traditional interpolation, so they are recommended for use in spatial of rainfall erosivity in Espírito Santo State. Figure 2 presents the spatial distribution of the annual $\mathrm{EI}_{30}$ and $\mathrm{KE}>25$ indices calculated with $\mathrm{KE}$ computed by the use of WM equation and interpolated using the developed ANNs.

\section{CONCLUSIONS}

Based on the presented results we can conclude that:

1. The use of synthetic rainfall series is a promising alternative to estimate the rainfall erosivity at locations without pluviographic data availability;

2. There were no significant differences in $\mathrm{EI}_{30}$ and KE $>25$ rainfall erosivity indices estimated using two rainfall kinetic energy equations that were evaluated;

3. Artificial neural networks presented better performance than IDW and Kriging to spatial interpolate rainfall erosivity values in Espirito Santo State.

\section{ACKNOWLEDGMENTS}

The authors thanks Fundação de Amparo à Pesquisa do Espírito Santo (FAPES) for the financial support of (Process number 35613165/06.).

\section{RESUMO}

Dentre as características da precipitação aquela que expressa sua capacidade em promover a erosão do solo é denominada erosividade das chuvas (R), sendo comumente representada pelos índices $\mathrm{EI}_{30}$ e $\mathrm{KE}>25$. A 


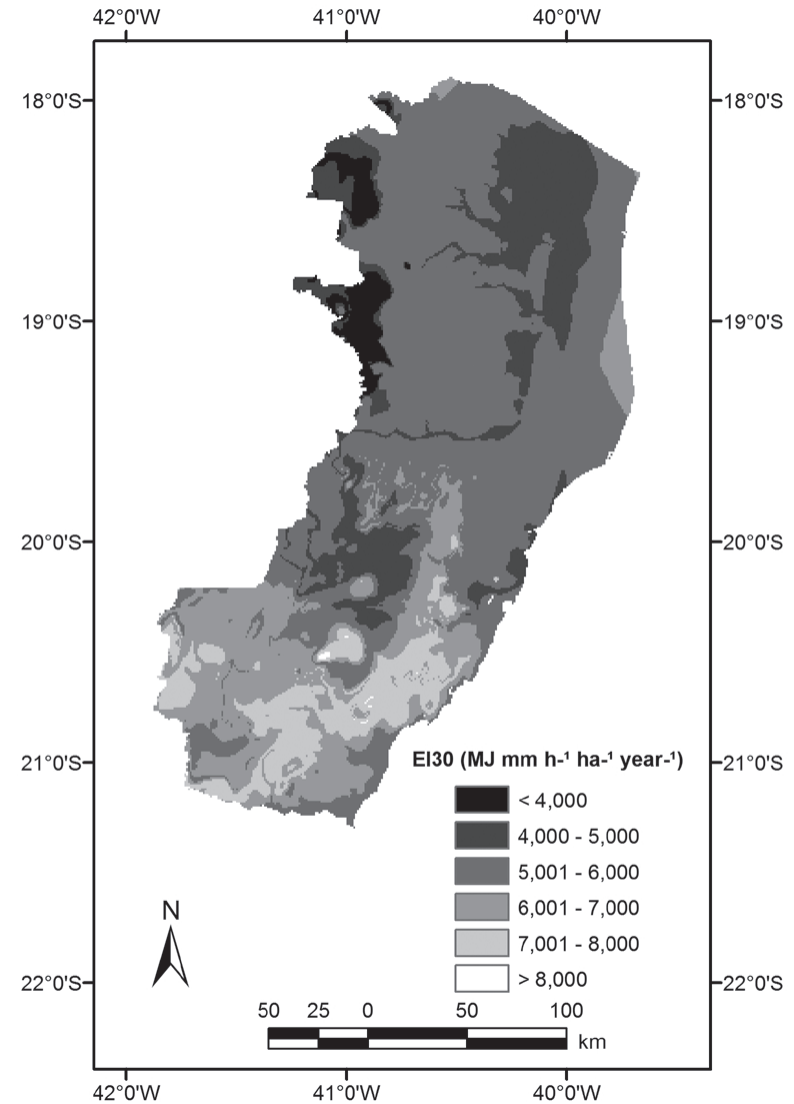

Figure 2 - Spatial distribution of the annual $\mathrm{EI}_{30} \mathbf{( A )}$ and $\mathrm{KE}>2$ equation and interpolated using the developed ANNs.

determinação destes indices requer a disponibilidade de series de dados pluviográficos, que são de difícil acesso no Brasil. O presente artigo descreve o uso de séries sintéticas de dados pluviográficos para calcular os índices $\mathrm{EI}_{30}$ e KE $>25$ no Estado do Espírito Santo (Brasil). Redes neurais artificiais (ANNs) também foram desenvolvidas para promover a interpolação espacial dos valores de $\mathrm{R}$ no Espírito Santo. Os valores calculados para os índices $\mathrm{EI}_{30}$ e $\mathrm{KE}>25$ foram próximos àqueles encontrados em áreas pluviométricamente homegêneas próximas, indicando a aplicabilidade do uso de séries sintéticas de dados pluviográficos. As redes neurais artificiais consistiram em interpoladores espacial melhores que os métodos de inverso da potência da distância e krigagem para a espacialização dos índices de erosividade no Espírito Santo.

Palavras-chave: interpolação, gerador climático, conservação do solo, equação universal de perdas de solo.

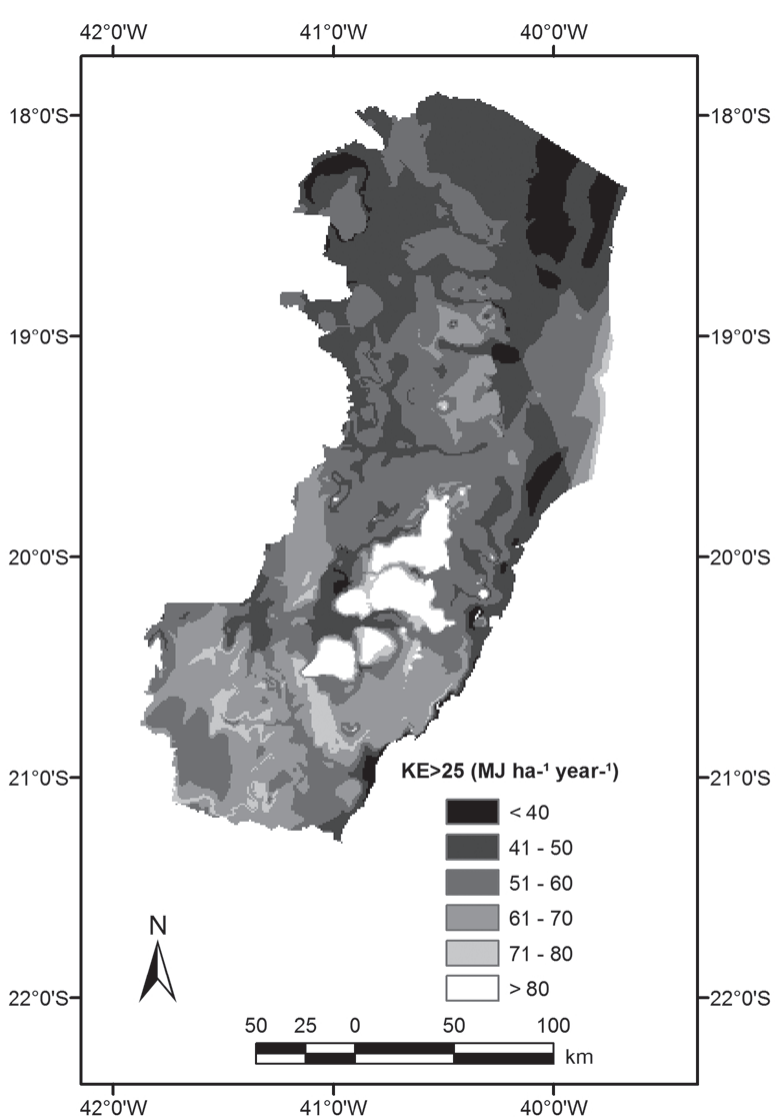

(B) indices calculated with KE computed by the use of WM

\section{REFERENCES}

Akkala A, Devabhaktuni V AND Kumar A. 2010. Interpolation techniques and associated software for environmental data. Environ Prog Sustainable Energy 29: 134-141.

Alves Sobrinho T, Pertussatti CA, Rebucci LCS AND OLIVEIRA PTS. 2011. Estimation of local rainfall erosivity using artificial neural network. R Ambiente \& Água 6: 246-254. (in Portuguese).

ANGULO-MARTínEZ M, LÓPEZ-VICENTE M, VicENTE-SERRANO SM AND BEGUERÍA S. 2009. Mapping rainfall erosivity at a regional scale: a comparison of interpolation methods in the Ebro Basin (NE Spain). Hydrol Earth Syst Sci 13: 1907-1920.

Aquino RF, AVAnzi JC, Silva MLN, SÁfADi T AND CuRi N. 2008. Use of time series models for predicting monther erosivity in Lavras, MG. R Bras Agromet 16: 205-210. (in Portuguese).

BAENA LGN, Pruski FF, Moreira MC, SOUZA VBC, ZanetTi SS AND OLIVEIRA VPS. 2005. Software for Generating Synthetic Series of Climatic Data. Eng Agricult 13: 210220. (in Portuguese). 
Baskan O, Cebel H, AKgul S and ERPul G. 2010. Conditional simulation of USLE/RUSLE soil erodibility factor by geostatistics in a Mediterranean Catchment, Turkey. Environ Earth Sci 60: 1179-1187.

Beguería S And Vicente-Serrano SM. 2006. Mapping the hazard of extreme rainfall by peaks over threshold extreme value analysis and spatial regression techniques. J Appl Meteorol 45: 108-124.

Bernardos PG AND VosniaKos GC. 2007. Optimizing feedforward artificial neural network architecture. Eng Appl Artif Intell 20: 365-382.

BIAŁOBRZEWSKI I. 2008. Neural modeling of relative air humidity. Comput Electron Agric 60: 1-7.

CABEDA MSV. 1976. Computation of storm EI value. West Lafayette: Purdue University, 6 p.

Capolongo D, Diodato N, Mannaerts CM, Piccarreta M AND STROBL RO. 2008. Analyzing temporal changes in climate erosivity using a simplified rainfall erosivity model in Basilicata (southern Italy). J Hydrol 356: 119-130.

Carvalho DF, Montebeller CA, Franco EM, VAlCARCEl RAND BERTOL I. 2005. Rainfall patterns and erosion indices at Seropédica and Nova Friburgo, Rio de Janeiro - Brazil. R Bras Eng Agríc Ambiental 9: 7-14. (in Portuguese).

Castro FS, Pezzopane Jem, Cecílio RA, Pezzopane JRM AND XAVIER AC. 2010. Evaluation of the performance of the different methods of interpolaters for parameters of the climatologic water balance. R Bras Eng Agríc Ambiental 14: 871-880. (in Portuguese).

Foster GR, McCoOl KG, RENARD KG AND MOLDENHAUER WC. 1981. Conversion of the universal soil loss equation to SI metric units. J Soil Water Cons 36: 355-359.

Gonçalves FA, Silva DD, Pruski FF, CARVAlho DF AND CRUZ ES. 2006. Indices and spatialization of rainfall erosivity in Rio de Janeiro State, Brazil. R Bras Eng Agríc Ambiental 10: 269-276. (in Portuguese).

GOOVAERTS P. 1999. Using elevation to aid the geostatistical mapping of rainfall erosivity. Catena 34: 227-242.

Hagan MT, Demuth HB AND BeALE M. 1996. Neural network design. Boston, PWS publishing company.

Hernani LC, Freitas PL, Pruski FF, De Maria IC, CAstro FilHo C AND LANDERS JC. 2002. A erosão e seu impacto. In: MANZATTO CV ET AL. (Eds), Uso agrícola dos solos brasileiros. Rio de Janeiro, EMBRAPA, p. 47-60. (in Portuguese).

Hoyos N. 2005. Spatial modeling of soil erosion potential in a tropical watershed of the Colombian Andes. Catena 63: 85-108.

Hoyos N, WAYLEn PR AND JARAmiLlo A. 2005. Seasonal and spatial patterns of erosivity in a tropical watershed of the Colombian Andes. J Hydrol 314: 177-191.

HUDSON NW. 1973. Soil conservation. Ithaca: Cornell University Press, 320 p.

Keller FILHo T, ASSAD ED AND LiMA PRSR. 2005. Rainfall homogeneous areas in Brazil. Pesq Agropec Bras 40: 311322. (in Portuguese).
MAIER HR AND DANDY GC. 2000. Neural networks for the prediction and forecasting of water resources variables: a review of modeling issues and applications. Environ Modell Softw 15: 101-123.

MARQUES JJGSM, Alvarenga RC, CURI N, SANTANA DP AND SILVA MLN. 1997. Rainfall erosivity índices, soil losses and erodibility factor for two soils from the Cerrado region - first approximation. R Bras Ci Solo 21: 427-434. (in Portuguese).

Martins SG, Avanzi JC, Silva MLN, Curi N, Norton LD AND FONSECA S. 2010. Rainfall erosivity and rainfall return period in the experimental watershed of Aracruz, in the coastal plain of Espírito Santo, Brazil. Rev Bras Ci Solo 34: 999-1004.

MATLAB SOFTWARE. 2000. Version 6.0, The MathWorks, Inc., Natick, MA.

Melo Júnior JCF, Sediyama GC, Ferreira PA AND LEAL BG. 2006. Spacial distribution of the rainfall frequencies in the Atlântico hydrographic region, east of Minas Gerais, Brazil. R Bras Eng Agríc Ambiental 10: 408-416. (in Portuguese).

Mello CR, SÁ MAC, Curi N, Nello JM, Viola MR AND SILVA AM. 2007. Monthly and annual rainfall erosivity for Minas Gerais State. Pesq Agropec Bras 42: 537-545. (in Portuguese).

MEN M, YU Z AND XU H. 2008. Study on the spatial pattern of rainfall erosivity based on geostatistics in Hebei Province, China. Front Agric China 2: 281-289.

Miranda F, DE FreitAs S AND FAGGion P. 2009. Integration and interpolation free air anomalies with basis in an ANN and kriging. Bol Ci Geod 15: 428-433. (in Portuguese).

Moreira MC, CECílio RA, PINTO FAC, LOMBARdi Neto F AND PRUSKI FF. 2006. Estimates of rainfall erosivity in São Paulo state by an artificial neural network. Rev Bras Ci Solo 30: 1069-1076. (in Portuguese).

Moreira MC, Pruski FF, OliveIRA TEC, PINTO FAC AND SiLVA DD. 2009. Artificial Neural Networks for Monthly Estimates of Rainfall Erosivity in the Minas Gerais State. Eng Agricult 17: 75-83. (in Portuguese).

OLIVEIRA VPS, ZANETTI SS AND PRUSKI FF. 2005a. CLIMABR part I: model for generation of synthetic series of precipitation. R Bras Eng Agríc Ambiental 9: 356-363. (in Portuguese).

OLIVEIRA VPS, ZANETTI SS AND PRUSKI FF. 2005b. CLIMABR part II: generation of precipitation profile. R Bras Eng Agríc Ambiental 9: 348-355. (in Portuguese).

PIMENTEL D ET AL. 1995. Environmental and economic costs of soil erosion and conservation benefits. Science 267: $1117-1123$

QI H, Gantzer CJ, Jung PK And LeE BL. 2000. Rainfall erosivity in the Republic of Korea. J Soil Water Conserv 55: $115-120$.

RENARD KG, Foster GR, WeEsies GA AND Porter JP. 1991. RUSLE: Revised Universal Soil Loss Equation. J Soil Water Conserv 46: 30-33. 
RoBINSON TP AND METTERNICHT G. 2006. Testing the performance of spatial interpolation techniques for mapping soil properties. Comput Electron Agric 50: 97-108.

SÁRKÖZY F. 1999. Gis functions - Interpolation. Periodica polytechnica Ser Civ Eng 43: 63-86.

SHAMSAD A, AZHARI MN, ISA MH, WAN HUSSIN WMA AND PARIDA BP. 2008. Development of an appropriate procedure for estimation of RUSLE $\mathrm{EI}_{30}$ index and preparation of erosivity maps for Pulau Penang in Peninsular Malaysia. Catena 72: 423-432.

SILVA AM. 2004. Rainfall erosivity map for Brazil. Catena 57: 251-259.

Silva MA, Silva MLN, Curi N, SANTOS GR, Marques JJGSM, MENEZES MD AND LEITE FP. 2010a. Evaluation and spatialization of rainfall erosivity in the Rio Doce Valley, central-eastern region of Minas Gerais, Brazil. Rev Bras Ci Solo 34: 1029-1039. (in Portuguese).

Silva MLN, Freitas PL, Blancaneaux P AND CURi N. 1997. Rainfall erosivity indices in the Goiânia region, Goiás State, Brazil. Pesq Agropec Bras 32: 977-985. (in Portuguese).

Silva RB, Iori P, ARMesto C AND Bendini HN. 2010b. Assessing Rainfall Erosivity with Artificial Neural Networks for the Ribeira Valley, Brazil. Int $\mathrm{J}$ Agron 2010: 1-7.

Silva SA, Lima JSS, SOUZA GS AND OliveIRA RB. 2010c. Variability of rainfall erosive potential for Espírito Santo State, Brazil. Irriga 15: 312-323. (in Portuguese).

SINHA SK AND WANG MC. 2007. Artificial neural network prediction models for soil compaction and permeability. Geotech Geol Eng 26: 47-64.

SIVAPRAGASAM C, ARUN VM AND GIRIDHAR D. 2010. A simple approach for improving spatial interpolation of rainfall using ANN. Meteorol Atmos Phys 109: 1-7.

SOUZA ECB, RiBEIRO SRA, BotelHo MF, KRUEGER CP AND CEnTENo JAS. 2006. Generation of isolines using GPR/ L1L2 data and artificial neural network technique. Acta Scient Tech 28: 205-212. (in Portuguese).
TEEGAVARAPU RSV. 2007. Use of universal function approximation in variance dependent surface interpolation method - an application in hydrology. J Hydrol 332: 16-29.

Telles TS, Guimarães MF AND DeChen SCF. 2011. The costs of soil erosion. Rev Bras Ci Solo 35: 287-298.

WAGNER CS AND MASSAMBAnI O. 1988. Analysis of the Wischmeier and Smith rainfall intensity-kinetic energy relationship and its applicability for São Paulo (Brazil) region. Rev Bras Ci Solo 12: 197-203. (in Portuguese).

WiLLMONT CJ. 1981. On the validation of models. Phys Geog 2: 184-194.

WISCHMEIER WH. 1959. A rainfall erosion index for a universal soil loss equations. Soil Sci Soc Am Proc 23: 246-249.

WISCHMEIER WH AND SMITH DD. 1958. Rainfall energy and its relationship to soil loss. Trans Am Geophys Union 39: 285-291.

WischmeIER WH AND SMITH DD. 1978. Predicting Rainfail Erosion Losses - A Guide to Conservation Planning, vol. 537 of Agriculture Handbook, USDA, Washington, DC, USA.

YIN S, XIE Y, NEARING MA AND WANG C. 2007. Estimation of rainfall erosivity using 5-to 60-minute fixed-interval rainfall data from China. Catena 70: 306-312.

YU B. 2002. Using CLIGEN to generate RUSLE climate inputs. Trans ASAE, 45: 993-1001.

ZANETTI SS, OLIVEIRA VPS AND PRUSKI FF. 2006. Validation of the model ClimaBR in relation to the number of wet days and to daily total precipitation. Eng Agríc 26: 96102. (in Portuguese).

ZHANG Q, WANG L AND WU F. 2008a. GIS-based assessment of soil erosion at Nihe Gou Catchment. Agric Sci China 7: 746-753.

ZHANG Y, LIU B, WANG Z AND ZHU Q. 2008b. Evaluation of CLIGEN for storm generation on the semiarid Loess Plateau in China. Catena 73: 1-9.

Zhang YG, NeARING MA, Zhang XC, XIE Y AND Wei H. 2010. Projected rainfall erosivity changes under climate change from multimodel and multiscenario projections in Northeast China. J Hydrol 384: 97-106. 